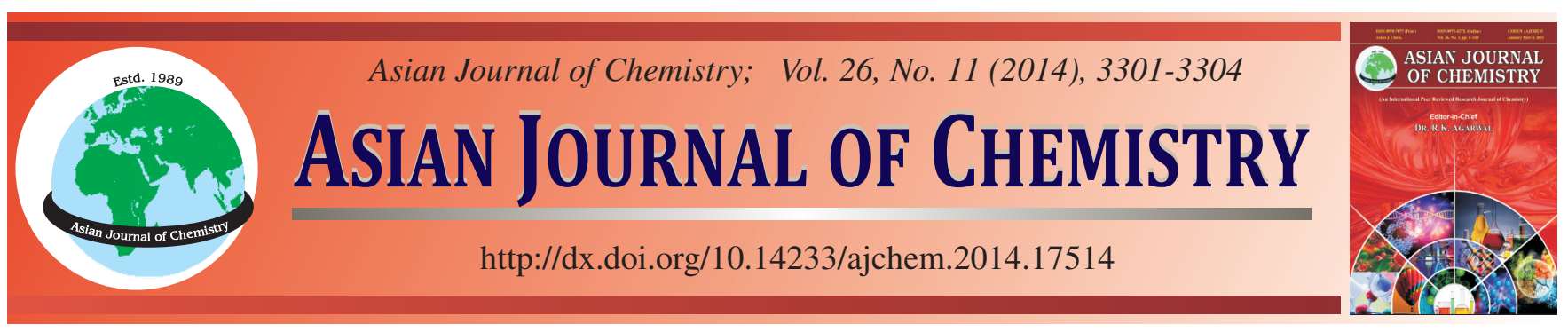

\title{
Application of Scavenger for Prevention and Remediation of Hydrogen Sulphide in Oil Exploitation
}

\author{
Yu Yang ${ }^{1, *}$, Hansen Sun ${ }^{2}$, Taotao Luo ${ }^{3}$, Xiaodong Peng ${ }^{4}$, Ruili Zhou ${ }^{5}$ and Shije Liu ${ }^{6}$
}

\begin{abstract}
${ }^{1}$ State Key Laboratory of Oil and Gas Reservoir Geology and Exploitation, Chengdu 610059, Sichuan Province, P.R. China ${ }^{2}$ China United Coalbed Methane Co. Ltd., Beijing 100011, P.R. China ${ }^{3}$ CCDC Drilling \& Production Engineering Technology Institute, Guanghan 618300, Sichuan Province, P.R. China ${ }^{4}$ Zhanjiang Branch of CNOOC Ltd., Zhanjiang 524057, Guangdong Province, P.R. China

${ }^{5}$ Engineering Research Institute of North China Branch Company of SINOPEC, Zhengzhou 450006 Henan Province, P.R. China ${ }^{6}$ Energy College of Chengdu University of Technology, Chengdu 610059, Sichuan Province, P.R. China
\end{abstract}

*Corresponding author: Tel: +86 13708056913; E-mail: 332482900@qq.com

\begin{abstract}
Hydrogen sulphide, a notorious toxic gas, has been found in some areas of Qing Hai Oilfield of the P.R. China, especially in the heavy oil blocks. Not only does it endanger the lives of operators, but it also causes corrosion damage on pipelines and engines. Both N80 and 20 \# type steel pipe have been tested with concentrations up to $200 \mathrm{ppm} \mathrm{H}_{2} \mathrm{~S}$, It has been found that the corrosion products are made up of the $\mathrm{Fe}, \mathrm{Cl}, \mathrm{S}$ and $\mathrm{Mn}$ elements. A new type of scavenger named TEM-10-15 has been adopted to lessen the damage of the $\mathrm{H}_{2} \mathrm{~S}$. Experiments carried out in laboratory show that this treatment agent can eliminate the effects of $\mathrm{H}_{2} \mathrm{~S}$ quickly and for a longer time. This method has also been used in on-site field trialsin the process of oil exploitation.
\end{abstract}

Keywords: Hydrogen sulphide, Corrosion, Corrosion inhibitor, Oil reservoir.

\section{INTRODUCTION}

Hydrogen sulphide $\left(\mathrm{H}_{2} \mathrm{~S}\right)$ has been found in some areas of Qing Hai Oilfield of the P.R. China, especially in the heavy oil blocks. With the drop of temperature and pressure of oil from underground to surface condition, the hydrogen sulphide can be observed flowing out of crude oil continuously, which causes stress corrosion fractures in the steel pipeline and rod pump and shortens the service life of production equipment, or even leads to accidents that may cause casualties ${ }^{1-6}$.

While the $\mathrm{H}_{2} \mathrm{~S}$ without aqueous phase has no corrosive effects on metal materials, it is corrosive when dissolved in water ${ }^{2,3}$. In wet $\mathrm{H}_{2} \mathrm{~S}$ corrosive environment, carbon steel equipment prone to uniform corrosion and wet $\mathrm{H}_{2} \mathrm{~S}$ stress corrosion cracking. In the aqueous solution of $\mathrm{H}_{2} \mathrm{~S}$, the embrittlement of steel is caused by molecular $\mathrm{H}_{2} \mathrm{~S}$ which is not dissociated ${ }^{2,7}$. This process is carried out in the following order ${ }^{5,7}$.

$$
\begin{gathered}
\mathrm{H}_{2} \mathrm{~S}+\mathrm{e} \longrightarrow \mathrm{H}_{2} \mathrm{~S}^{-} \\
\mathrm{H}_{2} \mathrm{~S}^{-} \longrightarrow \mathrm{HS}^{-}+\mathrm{H} \\
\mathrm{H} \longrightarrow \mathrm{H}^{+}+\mathrm{e} \\
\mathrm{HS}^{-}+\mathrm{H}^{+} \longrightarrow \mathrm{H}_{2} \mathrm{~S}
\end{gathered}
$$

The essence of wet $\mathrm{H}_{2} \mathrm{~S}$ stress cracking is hydrogen embrittlement. The major types can be classified as follows: Hydrogen blistering, hydrogen induced cracking, stress corrosion cracking and stress oriented hydrogen induced cracking $^{8}$. The hydrogen adsorbed on the surface of steel provides necessary condition for steel hydrogen permeation and hydrogen embrittlement ${ }^{7}$. When the hydrogen atoms diffuse inward to the internal surface of steel, it will produce a brittle layer, which leads to sulphide stress corrosion cracking and hydrogen induced cracking 9 .

Taken into account of the on-site circumstance, a series of indoor corrosion experiments are carried out on both of the N80 and 20 \# steel, to evaluate corrosion status and study the principle of anticorrosion.

\section{Corrosion of hydrogen sulphide}

Procedure: Prepare aqueous solution of sodium chloride and the corrosion specimen (standard $50 \mathrm{~mm} \times 10 \mathrm{~mm} \times 3 \mathrm{~mm}$ specimen). Fix the corrosion coupon on the bracket of SARII high-temperature and high-pressure dynamic corrosion test instrument. Add sodium chloride water and shut the reactor and wipe out oxygen with nitrogen gas. Input $\mathrm{H}_{2} \mathrm{~S}$ gas as required 
and the instrument is then heated and pressured to the specified conditions. The coupon is taken out after 10 days. After the corrosion products are cleared, the coupons are weighted and recorded. The average (overall) corrosion rate is calculated with the following equation ${ }^{10}$.

$$
\mathrm{Va}=8.76 \times 10^{4} \times \frac{\Delta \mathrm{W}}{(\mathrm{S} \times \mathrm{t} \times \rho)}
$$

where: Va: Average corrosion rate (mm/a); $\Delta \mathrm{W}$ : loss of coupon weight $(\mathrm{g}) ; \Delta \mathrm{W}_{0}$ : The weight loss of blank coupon $(\mathrm{g}) ; \mathrm{S}$ : coupon corrosion area $\left(\mathrm{cm}^{2}\right)$; t: corrosion time $(\mathrm{h}) ; \rho$ : coupon density $\left(\mathrm{g} / \mathrm{cm}^{3}\right)$.

The corrosion morphology of coupon surface can be analyzed with S-450 type scanning electron microscope. The elements, composition and structure of the sample surface film on corrosive product were measured using X-ray energy dispersive spectroscopy (OV9100/65). The implemental standard followedis "analytical scanning electron microscope general rule", JY/T010-1996".

Corrosion made by the hydrogen sulphide: To test the corrosion of the N80 and 20 \# steels in 200 ppm concentration of the hydrogen sulphide under various conditions. The reaction process lasts 10 days and the experiment is to be carried out at $45^{\circ} \mathrm{C}$. The experiment results are shown in Table- 1 . The S-450 scanning electron microscope was used to evaluate the corrosion morphology of two kinds of steel coupons under a variety of test conditions. The representative morphologies are shown in Figs. 1-3.

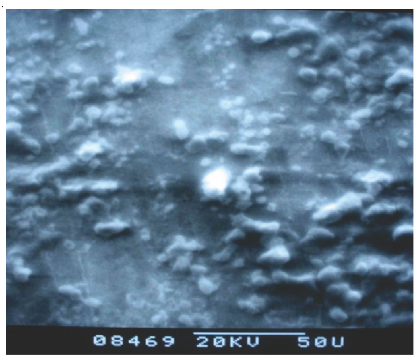

$20 \#$ steel $(\times 500)$

Fig. 1. Microstructure of the corrosion coupon under condition 1

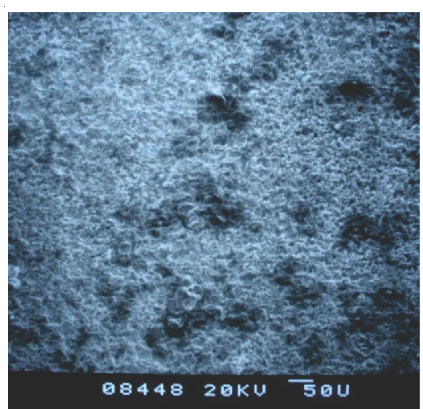

20\# steel $(\times 500)$

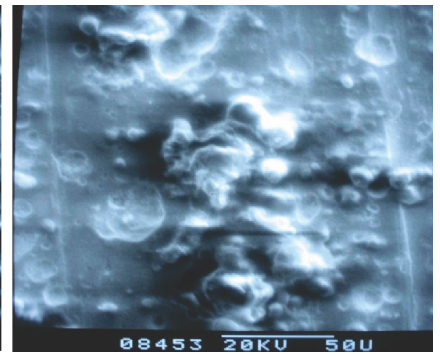

N80 steel $(\times 500)$

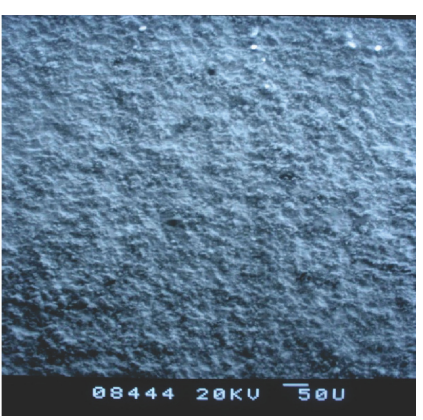

N80 steel $(\times 500)$
Fig. 2. Microstructure of the corrosion coupon under condition 2

Various results can be seen from Table-1. The results under condition 1 are that the corrosion rate of 20 \# steel coupon is $0.0311 \mathrm{~mm} / \mathrm{a}$, representing the moderate corrosion. The corrosion rate of $\mathrm{N} 80$ steel coupon is $0.0214 \mathrm{~mm} / \mathrm{a}$, showing mild corrosion and the corrosion degree is less serious than that of the 20 \# steel coupon. It can be seen from Fig. 1 that 20\#

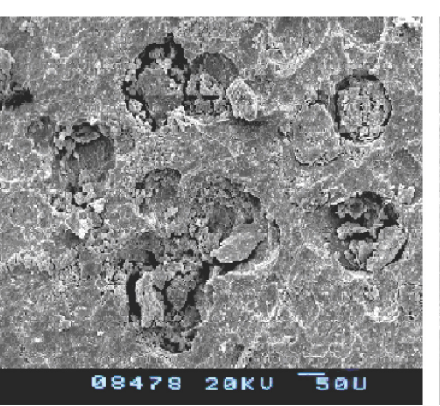

20\# steel $(\times 1000)$

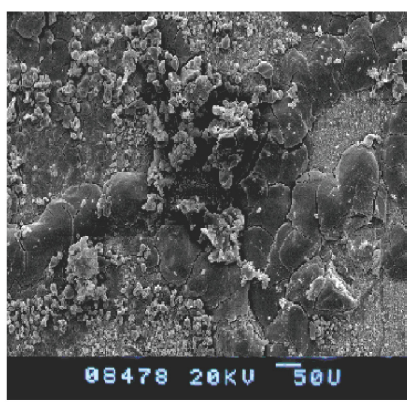

N80 steel $(\times 1000)$ steel coupon show shallow pitting after removing the corrosion products and the N80 typecoupon shows similar results as that of $20 \#$.

The results under condition 2 are that the corrosion rate of 20 \# steels is $0.0567 \mathrm{~mm} / \mathrm{a}$, which is moderate corrosion. The corrosion rate of N80 steels is $0.0345 \mathrm{~mm} / \mathrm{a}$, showing moderate corrosion. However, the corrosion is less serious than that of 20 \# steels. It can be seen from Fig. 2 that the 20 \# steel coupon show minor pitting after removing corrosion products and N80 coupon also shows similar pitting.

The results under condition 3 are that the corrosion rate of 20 \# steel is $0.0615 \mathrm{~mm} / \mathrm{a}$, showing moderate corrosion. The corrosion rate of $\mathrm{N} 80$ steel is $0.0412 \mathrm{~mm} / \mathrm{a}$, showing moderate corrosion, but the corrosion is less serious than that of the 20 \# steel. It can be concluded from Fig. 2 that 20 \# steel corrosion specimens shows obvious pitting after the removal of corrosion products and the pits are deeper. The N80 \# steel corrosion specimen also have pitting on the surface, but they are shallow ones.

By means of the energy dispersive analysis of the corrosion products on the corrosion coupon under three conditions, it can be concluded from Table- 2 that the corrosion products are mainly made up of the complex compounds of $\mathrm{Fe}, \mathrm{Cl}, \mathrm{S}$, $\mathrm{Mn}$ and other elements. The created corrosion process is realized by chloride ion to destroy the corrosion product films, as well as electrochemical corrosion effect of hydrogen sulphide ${ }^{3,9}$.

Elimination of the hydrogen sulphide: There are three methods to control $\mathrm{H}_{2} \mathrm{~S}$ corrosion on site. The first one is using corrosion resistant material or double metal composite pipe. The second one is by means of inner wall coating or non metal lining. The last one is using corrosion inhibitor ${ }^{6,8}$. Corrosion inhibitors have been updated from the early natural materials and inorganic salts to the modern high efficient organic compound with free pollution in the near 100 years $^{12-15}$. It is an economical and practical method used for oilfield and has the advantages of convenient operation, no need to replace equipment and so on.

Since hydrogen sulphide often appears in the oil and gas phase during oil field exploration and transport process, not only can hydrogen sulphide treatment agent absorb hydrogen sulphide in the gas phase, but can also adhere hydrogen sulphide to oil phase in a more stable form, preventing its overflow in the gaseous phase and doing little harm to pipes as well.

The experimental methods are as follows: Place a sealed $350 \mathrm{~mL}$ size container placed on an oscillator and the volume of fluid (oil or water) fixed at $200 \mathrm{~mL}$. Switch on the oscillator 


\begin{tabular}{|c|c|c|c|c|c|c|}
\hline \multicolumn{7}{|c|}{$\begin{array}{c}\text { TABLE-1 } \\
\text { CORROSION TEST OF SPECIMENS UNDER DIFFERENT CONDITIONS }\end{array}$} \\
\hline $\begin{array}{l}\text { Test under } \\
\text { conditions }\end{array}$ & Material & Weight loss (g) & $\begin{array}{l}\text { Surface area } \\
\quad\left(\mathrm{cm}^{2}\right)\end{array}$ & $\begin{array}{l}\text { Corrosion time } \\
\text { (d) }\end{array}$ & $\begin{array}{l}\text { Corrosion rate } \\
(\mathrm{mm} / \mathrm{a})\end{array}$ & $\begin{array}{l}\text { Average corrosion } \\
\text { rate }(\mathrm{mm} / \mathrm{a})\end{array}$ \\
\hline \multirow{8}{*}{$\begin{array}{c}\text { Condition } 1 \\
\text { (pressure: } 12 \mathrm{Mpa} \\
\text { Salinity: } 200000 \\
\mathrm{mg} / \mathrm{L} \text { ) }\end{array}$} & \multirow{4}{*}{ 20\# Steel } & 0.0019 & 13.90 & - & - & \multirow{4}{*}{0.0311} \\
\hline & & 0.0091 & 13.85 & 10 & 0.0306 & \\
\hline & & 0.0093 & 13.85 & 10 & 0.0312 & \\
\hline & & 0.0094 & 13.86 & 10 & 0.0315 & \\
\hline & \multirow{4}{*}{ N80 Steel } & 0.0022 & 13.86 & - & - & \multirow{4}{*}{0.0214} \\
\hline & & 0.0065 & 13.84 & 10 & 0.0218 & \\
\hline & & 0.0067 & 13.86 & 10 & 0.0225 & \\
\hline & & 0.0059 & 13.83 & 10 & 0.0198 & \\
\hline \multirow{8}{*}{$\begin{array}{c}\text { Condition } 2 \\
\text { (pressure: } 20 \mathrm{MPa} \\
\text { Salinity: } 200000 \\
\mathrm{mg} / \mathrm{L} \text { ) }\end{array}$} & \multirow{4}{*}{ 20\# Steel } & 0.0022 & 13.62 & - & - & \multirow{4}{*}{0.0567} \\
\hline & & 0.0165 & 13.91 & 10 & 0.0552 & \\
\hline & & 0.0169 & 13.77 & 10 & 0.0571 & \\
\hline & & 0.0173 & 13.88 & 10 & 0.0579 & \\
\hline & \multirow{4}{*}{ N80 Steel } & 0.0017 & 14.03 & - & - & \multirow{4}{*}{0.0345} \\
\hline & & 0.0106 & 13.98 & 10 & 0.0352 & \\
\hline & & 0.0103 & 13.97 & 10 & 0.0343 & \\
\hline & & 0.0102 & 13.92 & 10 & 0.0341 & \\
\hline \multirow{8}{*}{$\begin{array}{c}\text { Condition } 3 \\
\text { (pressure: } 60 \mathrm{MPa} \\
\text { Salinity: } 320000 \\
\mathrm{mg} / \mathrm{L} \text { ) }\end{array}$} & \multirow{4}{*}{ 20\# Steel } & 0.0020 & 13.82 & - & - & \multirow{4}{*}{0.0615} \\
\hline & & 0.0179 & 13.91 & 10 & 0.0598 & \\
\hline & & 0.0187 & 13.89 & 10 & 0.0626 & \\
\hline & & 0.0185 & 13.86 & 10 & 0.0621 & \\
\hline & \multirow{4}{*}{ N80 Steel } & 0.0022 & 13.66 & - & - & \multirow{4}{*}{0.0412} \\
\hline & & 0.0126 & 13.74 & 10 & 0.0426 & \\
\hline & & 0.0119 & 13.75 & 10 & 0.0403 & \\
\hline & & 0.0121 & 13.83 & 10 & 0.0407 & \\
\hline
\end{tabular}

\begin{tabular}{|c|c|c|c|c|c|c|}
\hline \multicolumn{7}{|c|}{$\begin{array}{c}\text { TABLE-2 } \\
\text { INGREDIENTS OF COUPON'S CORROSION }\end{array}$} \\
\hline \multirow{3}{*}{ Element } & \multicolumn{6}{|c|}{ Weight (\%) } \\
\hline & \multicolumn{2}{|c|}{ Condition 1} & \multicolumn{2}{|c|}{ Condition 2} & \multicolumn{2}{|c|}{ Condition 3} \\
\hline & 20\# steel & N80 steel & 20\# steel & N80 steel & $20 \#$ steel & N80 steel \\
\hline $\mathrm{C}$ & 0.19 & 0.37 & 0.27 & 0.35 & 0.24 & 0.37 \\
\hline $\mathrm{Fe}$ & 55.34 & 62.79 & 47.35 & 56.28 & 45.37 & 49.82 \\
\hline $\mathrm{Cl}$ & 21.13 & 20.01 & 29.63 & 23.80 & 36.50 & 28.03 \\
\hline$S$ & 21.97 & 14.43 & 21.68 & 17.23 & 16.71 & 19.52 \\
\hline $\mathrm{Si}$ & 0.34 & 0.26 & 0.19 & 0.37 & 0.31 & 0.32 \\
\hline V & - & 0.15 & - & 0.17 & - & 0.15 \\
\hline $\mathrm{Ni}$ & 0.21 & - & 0.12 & - & 0.17 & - \\
\hline Mn & 0.62 & 1.47 & 0.63 & 1.64 & 0.56 & 1.67 \\
\hline $\mathrm{Cr}$ & 0.11 & 0.14 & 0.11 & 0.15 & 0.14 & 0.11 \\
\hline
\end{tabular}

and input hydrogen sulphide into the container until it's concentration reaches $1000 \mathrm{mg} / \mathrm{L}$. Add certain amount of treatment agent and keep the system closed immediately. Have the fluid mixed and test gas hydrogen sulphide concentration with detector.

Aging time of hydrogen sulphide scavenger: The oil sample is taken from the on-site oil well. Input hydrogen sulphide. In a similar container at normal temperature, until the content is increased to $1000 \mathrm{mg} / \mathrm{L}$. The dosage of scavenger TEM-10-15 is $1 \mathrm{~mL}$. The experiment method is similar as that above. The required time totreat the hydrogen sulphide was studied.

It can be seen from the Fig. 4 that after the reaction of hydrogen sulphide treatment agent TEM-10-15, the concentration of hydrogen sulphide decreases rapidly, even reduces to near zero concentration at last. The hydrogen sulphide is removed faster in water samples but slower in crude oil, which is due to the fact that thesolubility of hydrogen sulphide in the crude oil is larger and hydrogen sulphide scavenger requires a longer time to react.

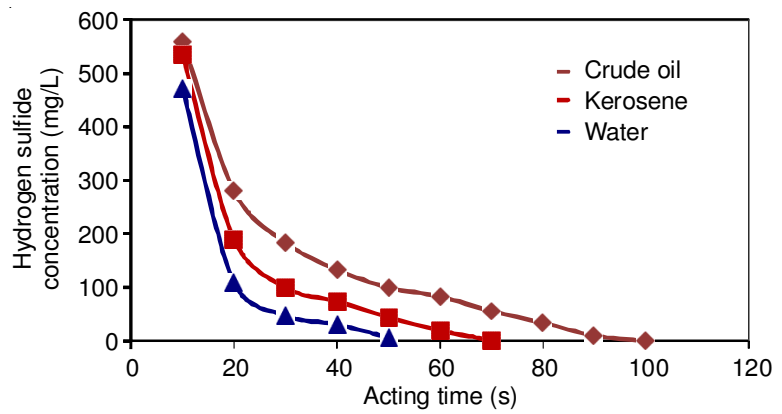

Fig. 4. Correlation between hydrogen sulfide concentration and acting time with different fluids

Influence of temperature on the scavenger: The volume of crude oil is set at $200 \mathrm{~mL}$ in a sealed containerand the hydrogen sulphide content is set at $1000 \mathrm{mg} / \mathrm{L}$. The dosage and the time for the scavenger required to absorb the hydrogen sulphide at different temperatures is tested.

It can be concluded from the Fig. 5 that the effective time of scavenger accelerates with the increase of temperature. The 
TABLE-3

ONSITE TREATMENT OF HYDROGEN SULFIDE

\begin{tabular}{ccccc}
\hline Wells tested & $\begin{array}{c}\text { Concentration of } \mathrm{H}_{2} \mathrm{~S} \\
(\mathrm{ppm})\end{array}$ & $\begin{array}{c}\text { TEM-10-15 consumption } \\
(\mathrm{kg})\end{array}$ & $\begin{array}{c}\text { Response time and the corresponding } \\
\text { concentration of } \mathrm{H}_{2} \mathrm{~S}\end{array}$ & $\begin{array}{c}\text { Time in effect } \\
(\mathrm{h})\end{array}$ \\
\hline Q6-12 & 127 & 25 & $20 \mathrm{~min} / 0 \mathrm{ppm}$ & 95 \\
S3-2-3 & $250+$ & 45 & $15 \mathrm{~min} / 0 \mathrm{ppm}$ & 115 \\
S3-2-2 & $200+$ & 25 & $3 \mathrm{~min} / 1 \mathrm{ppm}$ & 140 \\
\hline
\end{tabular}

amount of scavenger increases abruptly after the temperature reaches above $80^{\circ} \mathrm{C}$. It is due to the fact that the high temperature accelerates the reaction between the treatment agent and hydrogen sulphide and thus increases the consumption of the scavenger as well.

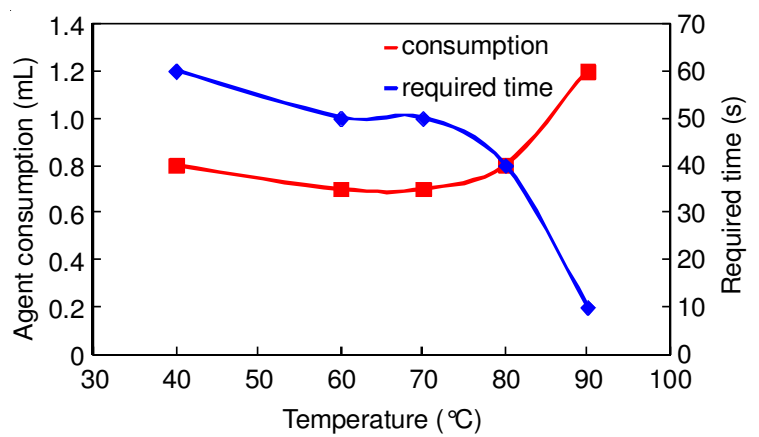

Fig. 5. Consumption of TEM-10-15 and the time required to adsorb hydrogen sulfide at different temperatures

The on-site effect of hydrogen sulphide treatment in the oil field: In the oil production plant of Qinghai oil field in P.R. China, scavenger TEM-10-15 is pumped into the casing head continuously, with the hydrogen sulphide content at the well head being monitored at the same time. The effect of onsite execution is shown in Table-3. It can be seen that the hydrogen sulphide treatment agent takes effect soon, absorbing hydrogen sulphide rapidly and preventing the generation of hydrogen sulphide in the long period.

\section{Conclusion}

With electron microscopy analysis, it can be concluded that most of the $\mathrm{H}_{2} \mathrm{~S}$ corrosion are point type corrosion and some are pitting type corrosion. The main mechanism of corrosion is the destruction of corrosion product film by the chloride ion, as well as the electrochemical corrosion of $\mathrm{H}_{2} \mathrm{~S}$. The corrosion products are mainly $\mathrm{Fe}, \mathrm{Cl}, \mathrm{S}, \mathrm{Mn}$ and other elements. During the indoor tests, it can been found that the hydrogen sulphide scavenger TEM-10-15 can take effect soon, absorb hydrogen sulphide rapidly and suppress the liberation of hydrogen sulphide for a long-term. Finally, On-site experiment also realized the hydrogen sulphide prevention successfully, proved the TEM-10-15 has reliable performance and can fully meet the on-site requirement.

\section{REFERENCES}

1. R. Sitthikhankaew, S. Predapitakkun, R.W. Kiattikomol, S. Pumhiran, S. Assabumrungrat and N. Laosiripojana, Energy Procedia, 9, 15 (2011).

2. N.U. Obeyesekere, A.R. Naraghi, L. Chen, S. Zhou, D. Abayarathna and $\mathrm{C}$, Tec, Environmentally Friendly Corrosion Inhibitors for Sweet and Sour Gas Corrosion, Document ID NACE-04733, CORROSION Conference, 28 March-1 April, New Orleans, Louisiana (2004).

3. Liu Wei, Pu Xiaolin and Bai Xiaodong, et al., Petroleum Drilling Techniq., 36, 83 (2008) (in Chinese).

4. Y.C. Zhang, H.H. Wang and Y.X. Li, J. Southwest Petroleum Univ., 31, 151 (2011)

5. L. Yonggang, Oil Field Equipment, 38, 62 (2009).

6. P. Mali, A.K. Garg and A. K. Sood, Measures Adopted to Reduce H2S Corrosion in Subsea Pipelines Used for Offshore Oil and Gas ProductionA Case Study ofCorrosion Effects of Hydrogen Sulphide and Carbon Dioxide in Oil Production Western Offshore, India, Document ID NACE-04743, CORROSION Conference, 28 March-1 April, New Orleans, Louisiana (2004).

7. Y.H. Bu, M.X. Ma and S.L. Guo, Corros. Prot. Petrochem. Ind., 28, 31 (2011).

8. C.S. Li, B. Zhao, Y.M. Zuo, L.X. Meng, Q.M. Sun and Z.H. Yang, Fault-Block Oil \& Gas Field, 15, 126 (2008) (in Chinese).

9. M.H. Achour, J. Kolts, P. Humble and R.L. Hudgins, Experimental Evaluation of Corrosion Inhibitor Performance in Presence of Iron Sulfide in $\mathrm{CO}_{2} / \mathrm{H}_{2} \mathrm{~S}$ Environment, Document ID NACE-08344, CORROSION Conference, 16-20 March, New Orleans, Louisiana (2008).

10. NACE Standard RP0775-2005, Preparation, Installation, Analysis and Interpretation of Corrosion Coupons in Oilfield Operations (Houston, TX: NACE).

11. State Education Commission, JY/T010-1996 Analytical Scanning Electron Microscope General Rule, Science and Technology Literature Publishing House, Beijing (1997) (in Chinese).

12. A.J. Szyprowski, Corrosion, 59, 68 (2003).

13. M. Gregg and S. Ramachandran, Review of Corrosion Inhibitor Developments and Testing for Offshore Oil and Gas Production Systems, Document ID NACE-04422, CORROSION Conference, 28 March-1 April, New Orleans, Louisiana (2004).

14. R. Hoppe, R.L. Martin, M.K. Pakulski and T.D. Schaffer, Corrosion Mitigation With Gas Hydrate Inhibitors. Paper SPE100474 presented at the SPE Gas Technology Symposium, Calgary, 15-17 May (2006).

15. J.A. Dougherty, Aggressive Agents as Corrosion Inhibitors in Gas and Oil Production, Document ID NACE-04423, CORROSION Conference, 28 March-1 April, New Orleans, Louisiana (2004). 